AGH DRILLING, OIL, GAS • Vol. 35 • No. 1 • 2018

http://dx.doi.org/10.7494/drill.2018.35.1.41

\author{
Anna Turkiewicz*, Piotr Kapusta*
}

\title{
ASSESSMENT OF THE POSSIBILITY \\ OF ENZYMATIC DECOMPOSITION \\ OF CELLULOSE BLOCKERS
}

\section{INTRODUCTION}

The appropriate choice of the method of selecting the type and graining of sealing materials for blocking pores and reducing the loss of drilling muds into rock formations is a very important issue in the technology of drilling fluids. Studies on reducing the loss of drilling fluids in the drilling process have been the subject of a lot of research works, including at the Oil and Gas Institute [1]. Among organic blockers, attention should be drawn to preparations made of organic cellulose. They are widely used as additives to drilling muds [5]. This type of blocker effectively seals the three-hole zone and is added directly to the circulating mud. The addition of the blocker to the mud in the amount of e.g. $15-30 \mathrm{~kg} / \mathrm{m}^{3}$ protects the rocks of the well-screen adjacent zone from penetrating of the solid phase and the mud filtrate into it, reduces the loss of the mud as well as friction forces in the borehole.

Some organic blockers are available as a powder and also contain fibres and flakes of natural cellulose. This product does not dissolve in water and remains in the drilling mud as a solid phase. It is resistant to temperatures up to $200^{\circ} \mathrm{C}$. Cellulose blockers belong to the group of non-toxic and naturally biodegradable products. Laboratory tests about the impact of the mud with an addition of a cellulose blocker on changes in the permeability of reservoir rocks were conducted at the Oil and Gas Institute in Cracow. On the basis of the performed tests, it was found that cellulose products added to the drilling liquid at the specified concentration are safe for the deposit and do not generate unfavourable changes in the permeability of the reservoir rock.

* Oil and Gas Institute - National Research Institute, Krakow, Poland 
Generally, one of the areas where the oil industry pays more and more attention is to ensure the stability of a borehole, and thus to understand the rules of loss of mud, fracturing of the layers due to its too high weight, as well as pouring and swelling of the borehole walls. All these activities are particularly important in the case of drilling holes in difficult geological conditions.

The applied technical solutions in the area of problems with the losses of mud and of circulation should include both prevention and corrective methods. It is also important that the losses are limited when they appear, or to plan drilling so as to prevent them. In the previous drilling practice, the drilling liquid losses occurring during the drilling of a hole were eliminated by increasing viscosity of the circulating drilling mud or by using various additives thickening it. Selection of appropriate organic blockers that would effectively seal the deposit is the subject of research in a lot of scientific centres. The sets of blockers properly selected for the potassium-polymer drilling mud effectively reduce its penetration into the deposit, and the maximum particle size of materials should be matched to the expected maximum size of rock pores [6]. The usability of a given organic locator in the drilling liquid technology is determined not only by its graining and other utility and physicochemical parameters, but also by the ease of removing a borehole from the wall.

Historically, enzymes have been used in the oil industry both for improving the characteristics of a ray of biopolymers in the industry and as breakers for biopolymer gels [3]. Enzymatic products are also used in industrial treatments based on enzymatic enhanced oil recovery (EEOR) [2].

This paper deals with this aspect and concerns the method of removing a cellulose blocker and its degradation.

\section{MATERIAL AND METHODS}

Two samples of cellulose blockers (called K-200 and GM-6), differing in the graining degree, were selected for laboratory tests. The K-200 blocker is a loose product - a powder with small graining. However, the GM-6 product is in the form of a coarse-grained granulate. The aim of the research was to determine whether and to what extent the tested substances are biodegradable with the use of enzymes. The above cellulose blockers were subjected to enzymatic preparations. They represent a group of protein cellulolytic compounds with properties catalysing the decomposition reaction of bonds linking individual particles of polysaccharide compounds, such as cellulose, starch and their chemical derivatives. In the global oil industry, products such as biopreparations (with the content of live cultures of microorganisms) as well as enzyme-based products are used. 
In the laboratory works on the assessment of opportunities and the degree of enzymatic decomposition of blockers, four products containing cellulolytic enzymes were applied. Their properties are briefly described below.

\section{Enzymatic product no. 1 (called Optiflow RC 2.0)}

The above product is liquid yellow substance acting in the environment with $\mathrm{pH}$ in the range of 3.5 to 6.5 and at the temperature of below $50^{\circ} \mathrm{C}$.

\section{Enzymatic product no. 2 (called Rohament CL)}

It is a liquid light brown product acting in the environment with $\mathrm{pH}$ in the range of 3.0 to 7.0, while the optimum operation of the product occurs at $\mathrm{pH}$ of 4.0 to 5.0.

\section{Enzymatic product no. 3 (called Rohament CP)}

It is a product in the form of a light beige, light brown after dissolution, powder. It acts in the environment with $\mathrm{pH}$ ranging from 3.0 to 7.0. The optimum operation of this product is at $\mathrm{pH}$ of 4.0 to 5.0.

\section{Enzymatic product no. 4 (called Cellupract)}

This product is a dark brown liquid. It acts in the environment with $\mathrm{pH}$ ranging from 3.0 to 7.0 .

In order to assess the course of the enzymatic process, Miller's colorimetric method [4] and the gravimetric method were applied. Test samples were prepared by weighing $10 \mathrm{~g}$ of K-200 blocker into five sterile glass bottles with ground-glass stoppers with a capacity of $300 \mathrm{ml}$. Similarly, $10 \mathrm{~g}$ of GM-6 blocker was weighed into the same five bottles. Subsequently, aqueous solutions of two tested enzymatic products with the concentration of $20 \%$ by volume were prepared according to the manufacturer's recommendations. As part of the first test series, test samples with the content of the first finegrained cellulose blocker (called K-200) were made and marked as follows:

1. Control sample A - containing $10 \mathrm{~g}$ of blocker and $100 \mathrm{ml}$ of distilled water.

2. Sample A1 - $10 \mathrm{~g}$ of blocker and $100 \mathrm{ml}$ of enzymatic product solution no. 1 .

3. Sample A2 - $10 \mathrm{~g}$ of blocker and $100 \mathrm{ml}$ of enzymatic product solution no. 2.

4. Sample A3 - $10 \mathrm{~g}$ of blocker and $100 \mathrm{ml}$ of enzymatic product solution no. 3 .

5. Sample A4-10 g of blocker and $100 \mathrm{ml}$ of enzymatic product solution no. 4 . 
Within the second series of the research, test samples containing coarse-grained cellulose substance (called GM-6) were made and marked as follows:

1. Control sample B - containing $10 \mathrm{~g}$ of blocker and $100 \mathrm{ml}$ of distilled water.

2. Sample B1 - $10 \mathrm{~g}$ of blocker and $100 \mathrm{ml}$ of enzymatic product solution no. 1 .

3. Sample B2 - $10 \mathrm{~g}$ of blocker and $100 \mathrm{ml}$ of enzymatic product solution no. 2.

4. Sample B3 - $10 \mathrm{~g}$ of blocker and $100 \mathrm{ml}$ of enzymatic product solution no. 3 .

5. Sample B4 - $10 \mathrm{~g}$ of blocker and $100 \mathrm{ml}$ of enzymatic product solution no. 4.

After adding the specified liquid enzymatic product (according to the above description) to samples containing the blocker, $\mathrm{pH}$ of each solution was established at the level of $4.5 \pm 0.1$ with the use of $2 \mathrm{~N}$ of $\mathrm{HCl}$ solution. The purpose of this procedure was to create conditions for the cellulose degradation reaction, the most similar to the optimum $\mathrm{pH}$ for the course of the enzymatic reaction.

The above-mentioned samples were incubated at $30^{\circ} \mathrm{C}$. After 48 hours of incubation, the first tests were conducted to determine whether the enzymatic degradation of the polysaccharide polymer such as cellulose began in the tested fluids. As already mentioned, these tests were conducted by the Miller's colorimetric method. Since the initial colorimetric analysis revealed the presence of monomer (i.e. glucose being the final product of the polymer decomposition reaction) in each of the tested samples, it was possible to use the quantitative method of evaluation of degradation degree in the further part of the work. After applying the first method, samples of all test fluids and control samples in the presence of the indicator and after heating in a water bath changed their colour from yellow to dark red which proved the presence of free glucose in the solution. Only control samples (containing no enzyme) did not change their colour and remained yellow. This colour resulted from the colour of the indicator, i.e. the dinitrosalicylic acid derivative.

In the further part of the work, the gravimetric method was selected in the quantitative assessment of the degree of blocker degradation. This method consists in comparing the quantity of the blocker (dry matter) after a specified time of enzyme impact with the quantity of the blocker in the control samples (containing no enzyme). In the first stage of the research, the degree of cellulose degradation was determined by weight after 30 days of incubation. The entire experiment was then repeated exactly according to the procedure described above, where the time of incubation of the samples was extended and the final result was obtained after 40 days since the beginning of the research series (these samples were marked with the symbols $\mathrm{C}$ and D). Test results of all test samples were collected in tabular form (Tabs 1-4).

\section{RESULTS}

After the incubation of the test samples within the first and second research series, the degree of decomposition of the two cellulose products was estimated. The first signs 
of the course of the decomposition reaction of blockers in the form of the presence of free glucose (monomer) in the test solutions occurred just after two days since the beginning of the experiment. However, significant quantitative changes made as a result of the biodegradation process appeared after quite a long period of time, i.e. after approx. 30-40 days of incubation.

Tables 1-4 present the results of tests on the degradation degree of selected blockers after incubation at $30^{\circ} \mathrm{C}$.

\section{Table 1}

Results of the K-200 organic blocker degradation test after 20 days of enzymatic products impact

\begin{tabular}{|c|c|c|}
\hline Test sample & $\begin{array}{c}\text { Dry matter of the blocker } \\
\text { after 30-day incubation } \\
{[\mathrm{g}]}\end{array}$ & $\begin{array}{c}\text { Loss of the blocker dry matter } \\
\text { [\% by weight] } \\
\text { as a result of the degradation } \\
\text { process }\end{array}$ \\
\hline A1 & 8.2 & 18 \\
\hline A2 & 6.9 & 31 \\
\hline A3 & 6.2 & 32 \\
\hline A4 & 6.8 & 0.1 \\
\hline Control sample A & 9.9 & 38 \\
\hline
\end{tabular}

Table 2

Results of the K-200 organic blocker degradation test after 30 days of enzymatic products impact

\begin{tabular}{|c|c|c|}
\hline Test sample & $\begin{array}{c}\text { Dry matter of the blocker } \\
\text { after 40-day incubation } \\
{[\mathrm{g}]}\end{array}$ & $\begin{array}{c}\text { Dry matter loss } \\
\text { [\% by weight] } \\
\text { as a result of the degradation } \\
\text { process }\end{array}$ \\
\hline $\mathrm{C} 1$ & 8.1 & 19 \\
\hline $\mathrm{C} 2$ & 6.4 & 36 \\
\hline $\mathrm{C} 3$ & 4.7 & 33 \\
\hline $\mathrm{C} 4$ & 6.8 & 0.3 \\
\hline Control sample C & 9.7 & \\
\hline
\end{tabular}


Table 3

Results of the G-M6 organic blocker degradation test after 20 days of enzymatic products impact

\begin{tabular}{|c|c|c|}
\hline Test sample & $\begin{array}{c}\text { Dry matter of the blocker } \\
\text { after 30-day incubation } \\
{[\mathrm{g}]}\end{array}$ & $\begin{array}{c}\text { Dry matter loss } \\
\text { [\% by weight] } \\
\text { as a result of the degradation } \\
\text { process }\end{array}$ \\
\hline B1 & 8.6 & 14 \\
\hline B2 & 8.0 & 20 \\
\hline B3 & 6.8 & 32 \\
\hline B4 & 6.9 & 31 \\
\hline Control sample B & 9.9 & 0.1 \\
\hline
\end{tabular}

Table 4

Results of the G-M6 organic blocker degradation test after 30 days of enzymatic products impact

\begin{tabular}{|c|c|c|}
\hline Test sample & $\begin{array}{c}\text { Dry matter of the blocker } \\
\text { after 40-day incubation } \\
{[\mathrm{g}]}\end{array}$ & $\begin{array}{c}\text { Gry matter loss } \\
\text { [\% by weight] } \\
\text { as a result of the degradation } \\
\text { process }\end{array}$ \\
\hline D1 & 8.1 & 19 \\
\hline D2 & 7.2 & 28 \\
\hline D3 & 6.6 & 34 \\
\hline D4 & 8.2 & 18 \\
\hline Control sample D & 9.9 & 0.1 \\
\hline
\end{tabular}

In the first and second experimental series, as a result of the reactions catalysed by cellulolytic substances, after 30-day incubation, no complete biodegradation of the tested blockers was found. However, the degree of enzymatic degradation was different in individual samples. Based on the obtained results, the most effective enzymatic product could be selected from among four products used in the laboratory work.

In the subsequent experimental series (after applying a 40-day incubation) the results of the tests in most of the samples were similar to the data obtained in the first 
and second series. The enzymatic preparation characterised by the highest effectiveness of action caused the degradation of approx. $38-53 \%$ by weight in fine-grained blocker tests. In contrast, the coarse-grained blocker was degraded in approx. 32-34\%.

The results of this work should be helpful in selecting an effective enzymatic preparation and the necessary duration of the impact in order to achieve the intended effect in the form of accelerating the destruction process of cellulose blockers. Therefore, two blockers with extreme graining (in the form of powder and granulate), which were subjected to enzymes that catalysed the cellulose biodegradation, were selected for the tests. As already mentioned, the maximum experimentally obtained matter loss due to a 30 -day incubation was $53 \%$ in the case of the K-200 blocker. However, in the case of the second GM-6 blocker with much larger a few millimetres grains, the degradation process was much slower. In borehole conditions, the decomposition degree of cellulose products may differ from the results obtained in the laboratory because the blocker is affected by additional factors, such as formation water, treatment fluids or autochthonous bacteria causing partial physicochemical changes of the polymer, which is cellulose. The existence or assurance of an appropriate $\mathrm{PH}$ of the environment is a very important aspect of the proper impact of enzymes and the course of reactions catalysed by them. As the manufacturers inform and the laboratory practice proves, the optimum effect of cellulolytic enzymes takes place in the adequately acidified environment in which the reaction takes place ( $\mathrm{pH}$ should be similar to $4-5$ and the $\mathrm{pH}$ highest level should not exceed 7.0). It should be noted that the effect of enzymes does not consist in directly destroying the bonds between individual monomers but they are only catalysts of the reaction. Therefore, their effect is much gentler than, for example, rapid destruction of the polymer with the participation of concentrated sulphuric or hydrochloric acid.

\section{REFERENCES}

[1] Błaż S.: Zapobieganie zanikom ptuczek $w$ formacje skalne $w$ procesie wiercenia [Preventing drilling fluid losses in the rock formations in the drilling process]. Nafta-Gaz, 2011, pp. 182-191.

[2] Gray J.L., Hartman A.R.: Enzyme enhanced oli recovery (EEOR) for near well bore treatment of oil and gas with greater than $50 \%$ barrel of oil equivalent (boe) gas production. Patent WO 2009032081A1, 2009.

[3] Harris R.E., McKay I.D.: New applications for enzymes in oil and gas production. SPE-50621-MS, 1998. 
[4] Miller G.L.: Use of dinitrosalicylic acid reagent for determination of reducing sugar. Analylical Chemistry, 31, 1959, pp. 427-433.

[5] World Oil Drilling, Completion and Workover Fluids. World Oil, 225 (6), 2004.

[6] Wójcikowski A.: Użytkowanie urządzeń obiegu płuczki wiertniczej [The use of drilling mud circulation equipment - Educational Materials of MEN] 311[40].Z2.02. Instytut Technologii Eksploatacji - Państwowy Instytut Badawczy [Publishing House of the Institute for Sustainable Technologies - National Research Institute], Radom 2007. 